\title{
The Effects of Grammar and Vocabulary Mastery on Students’ Reading Comprehension
}

\author{
Lilik Yuliawati \\ ASM BSI Jakarta \\ e-mail: lilik.lyw@bsi.ac.id
}

\begin{abstract}
The objective of the research is to know the effects of grammar and vocabulary mastery on students' reading comprehension. This research is a survey at private universities in Bekasi. The total sample of the research is 80 students. The data collection technique of grammar mastery, vocabulary mastery, and reading comprehension is by conducting three sets of multiple choice tests consisting of 30 questions for each test. The data analysis technique of the research is multiple linear regression analysis. Before conducting the regression analysis, there are some prerequisite tests, among others the normality, linearity, multicollinearity, and heteroscedasticity test. The result of the research is: 1) There is a significant effect of grammar and vocabulary mastery jointly on students' reading comprehension at private universities in Bekasi. 2) There is a significant effect of grammar mastery on students' reading comprehension at private universities in Bekasi. 3) There is a significant effect of vocabulary mastery on students' reading comprehension at private universities in Bekasi.
\end{abstract}

Key Word: Grammar Mastery, Vocabulary Mastery, Reading Comprehension

\section{INTRODUCTION}

Students are required to improve their English from junior high school until university. It is obvious that mastering English as a foreign language (EFL) requires mastering the four skills: listening, reading, speaking, and writing. Reading is one of fundamental skills a student needs to learn to succeed in life. It is also a receptive skill that allows people to get information from around the world. The reading demands of university study are not easy. Unfortunately, however, it is all too common for students to pay little attention to their own approaches to reading, that is, how they read, and how they can improve their effectiveness and speed of their reading.

At university, students may be expected to read a wide range of texts that include the course reading pack, lecture slides, books, journal articles, internet articles, newspapers, research reports, literature reviews, case studies, and strategic plans. Students may read to prepare for lectures and tutorials, review information addressed in lectures and tutorials, conduct research for assignments, or revise for examinations. Beyond being able to simply understand texts, students will need to critique them, evaluate them, compare and contrast them, and apply the information which is useful from them.

Based on the expectation above, it makes sense that students have to pay more attention to improve their reading skill to fulfill their study needs. Therefore, they need to have good reading comprehension to understand the content of their readings. Unfortunately, the students' reading comprehension is still poor. It can be seen from the results of the reading comprehension tests given by the lecturers which are below the expected standard. This problem could be affected by some factors related to the components of reading performance, such as reading habit, prior knowledge, grammar mastery, and vocabulary mastery.

The above condition triggers the writer to conduct this research by choosing grammar and vocabulary mastery as the predictors of students' reading comprehension. This research is conducted in order to know whether or not grammar and vocabulary mastery have significant effects on students' reading comprehension.

There are some definitions of grammar based on some experts. Swan (2005: xix) defines grammar as the rules that show how words are combined, arranged, or changed to show certain kinds of meaning. Whereas, Lado (1961: 141) states that grammar is the study of rules that are claimed to tell the students what he should and should not say in speaking language of the social educated class. In addition, Cook and Sutter (1980: 1) states that grammar is a set of rules by which people speak and write. These rules are not always understood consciously because the rules we refer to are those hardly anyone ever thinks about, but wish allow people to use their language easily and naturally most of the time.

To communicate intelligibly, to make sense with each sentence, a learner should know the grammar of the target language. According to Ur (1991: 76), "Grammar does not only affect how units of language are combined in order to 'look right'; it also affects their meaning”. It is supported by Knapp and Watkins (2005: 32) who said "Grammar is a name for the resources available to users of a language system for producing texts. A knowledge of grammar by a speaker or writer shifts language 
use from the implicit and unconscious to a conscious manipulation of language and choice of appropriate text”. From that statement, it is clear that grammar is one of the important things in English because it is not just to make the sentence good but also it will refers to its meaning.

Grammar mastery means the ability to absorb the theory of sentence (functions, units, or forms) and be able or capable of creating standard forms in accordance with the rules and regulations.

Swan (1985: 5) emphasizes the importance of grammar mastery to support the good use of language. In addition, Harmer (1991: 22) declared that grammatical knowledge is important for learners who want to have communicative competence. With good understanding on grammatical concepts, learners can avoid the use of incorrect structures.

In reading English texts, students often do not understand the meaning of sentence even though they understand all words contained in that sentence. It often occurs especially in long and complex sentences. By seeing those facts, there should be technique to help students in understanding the sentence, such as analysis of sentences, knowledge of punctuation, introduction of terms, and knowledge of key words.

Vocabulary cannot be separated from language skills because it plays an important role in understanding the language holistically. Hornby $(1995,133)$ says that vocabulary is a list of words with their meanings. It is the core of language.

According to Hatch and Brown (1995: 1), the term vocabulary refers to a list or set of words for a particular language or a list or a set of words that individual speaker of language might use.

Thornbury (2007: 14) states that vocabulary means a large collection of items. He adds that learning vocabulary is important because it enriches someone's knowledge of words. In reference to the reading comprehension, the students should acquire a number of vocabularies to get better understanding in reading an English text. Vocabulary as knowledge means the knowledge of a word not only implies a definition, but also implies how that words fits into the world.

Lehr, Osborn, and Hiebert (in Kamil and Hiebert, 2004: 2-3) define vocabulary as knowledge of words and word meaning in both oral and written language and in productive and receptive forms. More specifically, they use vocabulary to refer to "the kind of word that students must know to read increasingly demanding text with comprehension”. Nunan (1999: 101) says that vocabulary is more than lists of target language words. Vocabulary is part of the language system.
Vocabulary is central to English language teaching because without sufficient vocabulary students cannot understand others or express their own ideas. Wilkins (1972: 112) wrote that “... while without grammar very little can be conveyed, without vocabulary nothing can be conveyed”.

Vocabulary mastery can be defined as someone's proficiency in using words and their meaning appropriately in language. Vocabulary mastery is the process to comprehend English vocabulary learned from the messages communicated. By reading a text, learners will be accustomed to looking the dictionary up guessing the words and using the words in the context properly. Good vocabulary mastery will help the learners express their ideas precisely. By having many stocks of words, learners will be able to comprehend the reading materials, catch someone's talk, give response, speak fluently, and write some kinds of topics. On the contrary, if the learners are unfamiliar with the meaning of the words by those who address them, they will be unable to participate in conversation, ask for the information or express some ideas and thoughts.

\section{RESEARCH METHODOLOGY}

The method used in this study is survey method. Sasmoko (2004: 152) said that survey is data collecting from the limited cases in large numbers. The purpose of the survey is to collect information about the variables and not the information about individuals. There are three variables in this research: grammar mastery and vocabulary mastery as the independent variables and reading comprehension as the dependent variable. The analysis used for the hypothesis testing is multiple linear regressions.

The shape of this research design can be seen in the following scheme:

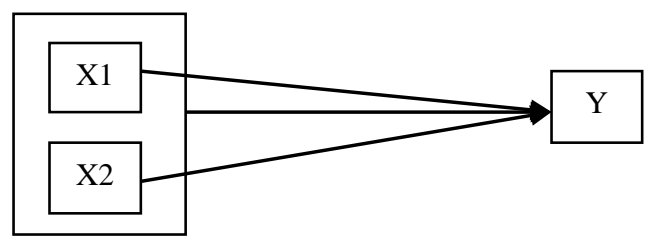

Figure 1. Research Design
Description:
X1 : Grammar Mastery
X2 : Vocabulary Mastery
Y : Students’ Reading Comprehension

The population in this research was second semester students of Bina Sarana Informatika Kaliabang Bekasi and Bina Sarana Informatika Cut Meutia 
Bekasi majoring Management of Informatics academic year 2016/2017.

Roscoe in Sugiyono (2013: 74) stated that in multivariate research, total respondent is at least ten times of total variables. Considering this statement, the writer took 80 students as the sample of this research. In choosing the sample, there are two universities: Bina Sarana Informatika Kaliabang Bekasi and Bina Sarana Informatika Cut Meutia Bekasi. The writer took 40 students from each university to be the samples. As a result, 80 students in second semester academic year 2016/2017 become the samples of this research.

The researcher collected the data by finding out on the field of the research. The data are collected by giving three sets of objective test as the instruments to the 80 students. Before the instruments are used to retrieve the data, they are firstly tested and executed on sample of students that do not include of the research but in the same population and level. It is to determine validity and reliability of the instrument. The correlation formula of Pearson Product Moment is used to test the validity of each question and the value of Cronbach's Alpha is used to measure the reliability of the instrument.

Test requirements of data analysis are used to determine whether the data are feasible or not by using statistical tools. The prerequisite tests include normality test, linearity test, multicollinearity test, and heteroscedasticity test.

The hypothesis test used simple multiple linear regressions. In this research, the overall analysis was carried out by a computer program of SPSS version 20.0 for windows.

\section{RESULT AND DISCUSSION}

\section{A. Data Description}

The data from the test of grammar, vocabulary, and reading comprehension which were taken from 80 respondents were used to analyze. The aim of the analysis is to find out and give information of the research findings based on the data and variables of the research. Therefore, all the data were analyzed by using SPSS version 20.0 for Windows in order to get the results.

The data description of grammar mastery (X1), vocabulary mastery (X2), and students' reading comprehension $(\mathrm{Y})$ are depicted in the following table.
Table 1. Description of Research Data Statistics

\begin{tabular}{|c|c|c|c|c|}
\hline & & $\begin{array}{l}\text { Grammar } \\
\text { Mastery }\end{array}$ & $\begin{array}{l}\text { Vocabular } \\
\text { y Mastery }\end{array}$ & $\begin{array}{c}\text { Reading } \\
\text { Comprehe } \\
\text { nsion }\end{array}$ \\
\hline \multirow[b]{2}{*}{$\mathrm{N}$} & Valid & 80 & 80 & 80 \\
\hline & $\begin{array}{l}\text { Missin } \\
\mathrm{g}\end{array}$ & 0 & 0 & 0 \\
\hline \multicolumn{2}{|c|}{ Mean } & 19.05 & 19.06 & 16.38 \\
\hline \multicolumn{2}{|c|}{ Median } & 19.00 & 19.00 & 17.00 \\
\hline \multicolumn{2}{|c|}{ Mode } & 19 & 17 & 20 \\
\hline \multicolumn{2}{|c|}{ Std. Deviation } & 5.507 & 5.646 & 4.915 \\
\hline \multicolumn{2}{|c|}{ Skewness } & .180 & -.045 & -.273 \\
\hline \multicolumn{2}{|c|}{$\begin{array}{l}\text { Std. Error of } \\
\text { Skewness }\end{array}$} & .269 & .269 & .269 \\
\hline \multicolumn{2}{|c|}{ Kurtosis } & -.955 & -1.142 & -.677 \\
\hline \multicolumn{2}{|c|}{$\begin{array}{l}\text { Std. Error of } \\
\text { Kurtosis }\end{array}$} & .532 & .532 & .532 \\
\hline \multicolumn{2}{|c|}{ Range } & 20 & 21 & 22 \\
\hline \multicolumn{2}{|c|}{ Minimum } & 9 & 7 & 4 \\
\hline \multicolumn{2}{|c|}{ Maximum } & 29 & 28 & 26 \\
\hline
\end{tabular}

\section{The Data of Grammar Mastery (X1)}

Data of grammar mastery are taken from an objective test in the form of multiple choices. The test consists of 30 items out of 80 respondents. Each item will be grade of 0 if it is incorrect and 1 if it is correct. It is known that the score are in the range 929. It means that the minimum score is 9 and the maximum score is 22 . The grammar mastery level of the respondents is on the average 19.05 (mean), standard deviation 5.507, score at the center of distribution 19.00 (median), and most frequently score in data set 19 (mode). The score of standard deviation is 5.507 means equal to $28.91 \%$ from the average score. It shows that the disparity of grammar mastery among the respondents is relatively low because as it is known that the standard deviation value describes how large the sample is. The higher the standard deviation value, the more sample data will spread (vary) from the average. Conversely, the lower the standard deviation value, the more homogeneous sample data. So it can be concluded that grammar mastery level of the respondents is homogenous.

From the description of table 1 above, it can be seen that the average score (19.05) and median score (19.00) is almost the same. It means that the data of grammar mastery level is quite representative. Meanwhile, the upper grammar mastery level which is higher than that of the average indicates that the respondents who possess the upper level of grammar mastery are more than those of the lower level ones. Furthermore, the graph of frequency histogram illustrates the distribution of grammar mastery as follows. 


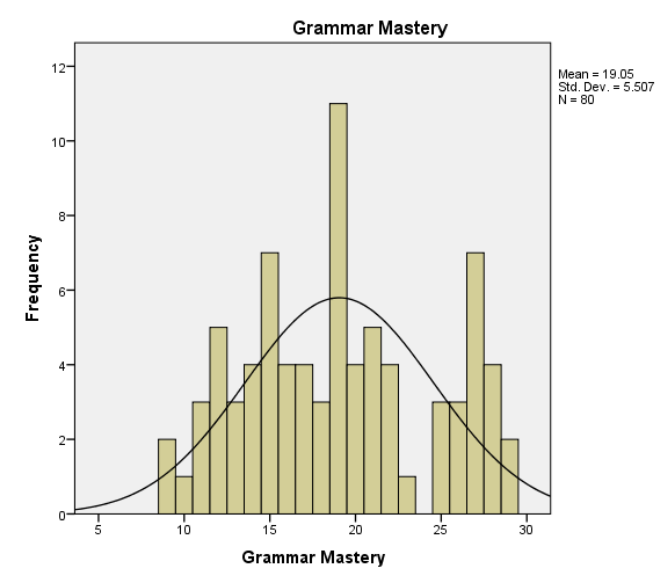

Figure 2. Histogram of Grammar Mastery

According to the figure 2 above, it can be concluded that the level of data spreading of grammar mastery of the respondents is relatively normal since the data which are scattered out of the normal curve are relatively small/negligible.

\section{The Data of Vocabulary Mastery (X2)}

Data of vocabulary mastery are taken from an objective test in the form of multiple choices. The test consists of 30 items out of 80 respondents. Each item will be grade of 0 if it is incorrect and 1 if it is correct. It is known that the score are in the range 728. It means that the minimum score is 7 and the maximum score is 28 . The vocabulary mastery level of the respondents is on the average 19.06 (mean), standard deviation 5.646, score at the center of distribution 19.00 (median), and most frequently score in data set 17 (mode). The score of standard deviation is 5.646 means equal to $29.62 \%$ from the average score. It shows that the disparity of vocabulary mastery among the respondents is relatively low because the higher the standard deviation value, the more sample data will spread (vary) from the average. Conversely, the lower the standard deviation value, the more homogeneous sample data. So it can be concluded that vocabulary mastery level of the respondents is homogenous.

From the description of table 4.1 above, it can be seen that the average score (19.06) and median score (19.00) is almost the same. It means that the data of vocabulary mastery level is quite representative. Meanwhile, the upper vocabulary mastery level which is higher than that of the average indicates that the respondents who possess the upper level of vocabulary mastery are more than those of the lower level ones.

Furthermore, the graph of frequency histogram illustrates the distribution of vocabulary mastery as follows.

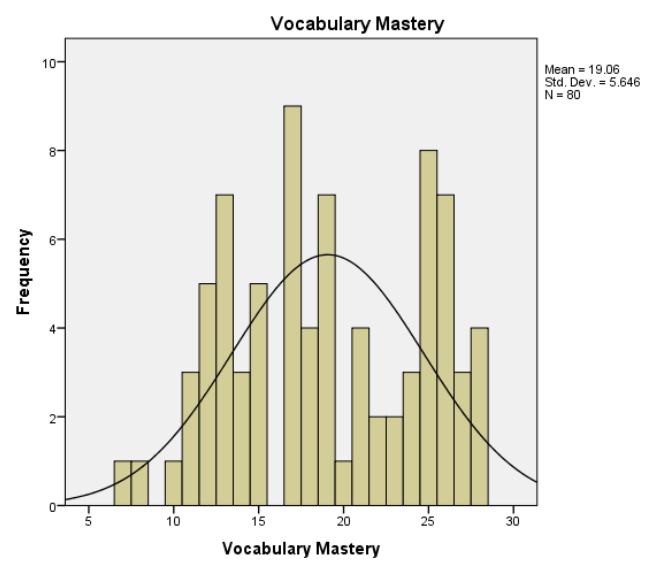

Figure 3. Histogram of Vocabulary Mastery

According to the figure 3 above, it can be concluded that the level of data spreading of vocabulary mastery of the respondents is relatively normal since the data which are scattered out of the normal curve are relatively small/negligible.

\section{The Data of Reading Comprehension (Y)}

Data of students' reading comprehension are taken from an objective test in the form of multiple choices. The test consists of 30 items out of 80 respondents. Each item will be grade of 0 if it is incorrect and 1 if it is correct. It is known that the score are in the range 4-26. It means that the minimum score is 4 and the maximum score is 26 . The grammar mastery level of the respondents is on the average 16.38 (mean), standard deviation 4.915, score at the center of distribution 17.00 (median), and most frequently score in data set 20 (mode). The score of standard deviation is 4.915 means equal to $30.01 \%$ from the average score. It shows that the disparity of reading comprehension among the respondents is relatively quite low. So it can be concluded that reading comprehension level of the respondents is homogenous.

From the description of table 4.1 above, it can be seen that the average score (16.38) and median score (17.00) is almost the same. It means that the data of reading comprehension level is quite representative. Meanwhile, the upper reading comprehension level which is higher than that of the average indicates that the respondents who possess the upper level of reading comprehension are more than those of the lower level ones.

Furthermore, the graph of frequency histogram illustrates the distribution of grammar mastery as follows. 


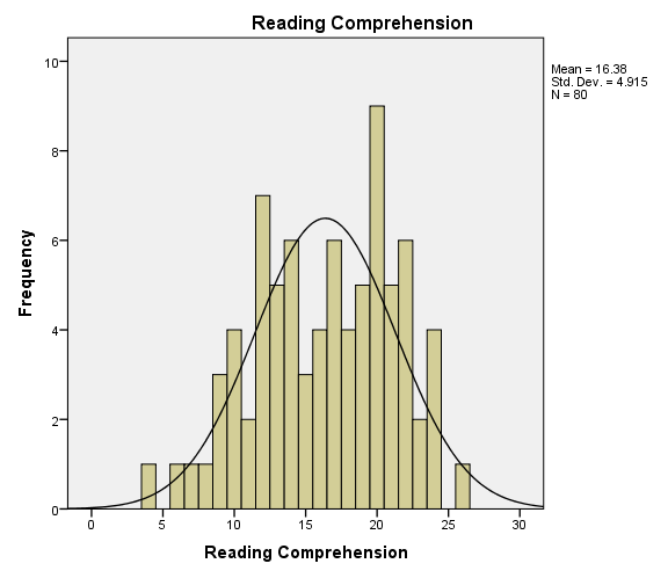

Figure 4. Histogram of Reading Comprehension

According to the figure 4 above, it can be concluded that the level of data spreading of reading comprehension of the respondents is relatively normal since the data which are scattered out of the normal curve are relatively small/negligible.

\section{B. Prerequisite Test of Data Analysis \\ 1. Normality Test}

Normality test is used to test and determined whether the data are normal or not so that $t_{0}$, partial correlation, multiple correlations, single regression, and multiple regressions can be analyzed. To test the normality of the data distribution, the researcher used Kolmogorov-Smirnov test through SPSS version 20.0 for Windows. According the criteria of that program, the set of data will be classified as normal if the Sig. value is above 0.05 . The result of normality test is stated as the following.

Table 2. Normality Test

One-Sample Kolmogorov-Smirnov Test

\begin{tabular}{|c|c|c|c|c|}
\hline & & $\begin{array}{l}\text { Grammar } \\
\text { Mastery }\end{array}$ & $\begin{array}{c}\text { Vocabula } \\
\text { ry } \\
\text { Mastery }\end{array}$ & $\begin{array}{c}\text { Reading } \\
\text { Compreh } \\
\text { ension }\end{array}$ \\
\hline $\mathrm{N}$ & & 80 & 80 & 80 \\
\hline \multirow[b]{2}{*}{$\begin{array}{l}\text { Normal } \\
\text { Parameters }{ }^{\mathrm{a}, \mathrm{b}}\end{array}$} & Mean & 19.05 & 19.06 & 16.38 \\
\hline & $\begin{array}{l}\text { Std. } \\
\text { Deviatio } \\
\mathrm{n}\end{array}$ & 5.507 & 5.646 & 4.915 \\
\hline \multirow{3}{*}{$\begin{array}{l}\text { Most Extreme } \\
\text { Differences }\end{array}$} & Absolute & .098 & .128 & .107 \\
\hline & Positive & .091 & .089 & .073 \\
\hline & Negative & -.098 & -.128 & -.107 \\
\hline \multicolumn{2}{|c|}{ Kolmogorov-Smirnov Z } & .872 & 1.149 & .958 \\
\hline \multicolumn{2}{|c|}{ Asymp. Sig. (2-tailed) } & .432 & 142 & 318 \\
\hline
\end{tabular}

From the table, we can see that all the Sig. value for grammar mastery, vocabulary mastery, and reading comprehension are stated consecutively by 0.432 , 0.142 , and 0.318 . Therefore, it can be concluded that all the data are distributed normally since the values of significance are all higher than 0.05 .

\section{Linearity Test}

Linearity test is an assumption in the regression analysis. It means that the regression line between $\mathrm{X}$ and $\mathrm{Y}$ forming whether or not in the linear line. If the line is not linear, it cannot be automatically continued to the next step.

The linearity test of the regression line can be calculated by using SPSS version 20.0 for Windows. According to the normal assumption, the set of data will be classified as linear in regression line if Sig. value is higher than 0.05 (Nurgiantoro et al., 2009: 329).

\section{a. Regression Line Linearity of the effect of X1 on $\mathbf{Y}$}

The linearity test result of regression line of the effect of grammar mastery (X1) on students' reading comprehension $(\mathrm{Y})$ can be seen in the following table:

Table 3. Linearity Test of Regression Line of X1 on $\mathbf{Y}$

\begin{tabular}{|c|c|c|c|c|c|c|c|}
\hline \multicolumn{8}{|c|}{ ANOVA Table } \\
\hline & & & $\begin{array}{c}\text { Sum of } \\
\text { Squares }\end{array}$ & $\mathrm{df}$ & $\begin{array}{l}\text { Mean } \\
\text { Square }\end{array}$ & $\mathrm{F}$ & Sig. \\
\hline \multirow{5}{*}{$\begin{array}{l}\text { Readin } \\
\text { g } \\
\text { Compr } \\
\text { ehensi } \\
\text { on * } \\
\text { Gram } \\
\text { mar } \\
\text { Master } \\
\text { y }\end{array}$} & \multirow{3}{*}{$\begin{array}{l}\text { Between } \\
\text { Groups }\end{array}$} & $\begin{array}{l}\text { (Combine } \\
\text { d) }\end{array}$ & 1336.305 & 19 & 70.332 & $\begin{array}{r}7.37 \\
2 \\
\end{array}$ & .000 \\
\hline & & Linearity & 1175.959 & 1 & $\begin{array}{r}1175.9 \\
59\end{array}$ & $\begin{array}{r}123 . \\
256\end{array}$ & .000 \\
\hline & & $\begin{array}{l}\text { Deviation } \\
\text { from } \\
\text { Linearity }\end{array}$ & 160.346 & 18 & 8.908 & .934 & .544 \\
\hline & \multicolumn{2}{|c|}{ Within Groups } & 572.445 & 60 & 9.541 & & \\
\hline & \multicolumn{2}{|l|}{ Total } & 1908.750 & 79 & & & \\
\hline
\end{tabular}

Based on the table 3 above, the Sig. value from Deviation from Linearity column is 0.544 which is higher than 0.05 . It means that the regression line which indicates the effect of grammar mastery (X1) on students' reading comprehension (Y) is linear.

b. Regression Line Linearity of the effect of X2 on $\mathbf{Y}$

The linearity test result of regression line of the effect of vocabulary mastery (X2) towards students' reading comprehension $(\mathrm{Y})$ can be seen in the following table:

Table 4. Linearity Test of Regression Line of X2 on Y

\begin{tabular}{|c|c|c|c|c|c|c|c|}
\hline \multicolumn{8}{|c|}{ ANOVA Table } \\
\hline & & & $\begin{array}{l}\text { Sum of } \\
\text { Squares }\end{array}$ & $\mathrm{Df}$ & $\begin{array}{l}\text { Mean } \\
\text { Square }\end{array}$ & $\mathrm{F}$ & Sig. \\
\hline \multirow{5}{*}{$\begin{array}{l}\text { Reading } \\
\text { Comprehe } \\
\text { nsion * } \\
\text { Vocabular } \\
\text { y Mastery }\end{array}$} & \multirow{3}{*}{$\begin{array}{l}\text { Betwee } \\
\text { n } \\
\text { Groups }\end{array}$} & $\begin{array}{l}\text { (Combin } \\
\text { ed) }\end{array}$ & $\begin{array}{r}1636.0 \\
69 \\
\end{array}$ & 19 & 86.109 & $\begin{array}{r}18 . \\
947\end{array}$ & .000 \\
\hline & & Linearity & $\begin{array}{r}1541.0 \\
38\end{array}$ & 1 & $\begin{array}{r}1541.03 \\
8\end{array}$ & $\begin{array}{r}339 \\
.08 \\
6 \\
\end{array}$ & .000 \\
\hline & & $\begin{array}{l}\text { Deviatio } \\
\mathrm{n} \text { from } \\
\text { Linearity }\end{array}$ & 95.032 & 18 & 5.280 & $\begin{array}{r}1.1 \\
62\end{array}$ & .321 \\
\hline & \multicolumn{2}{|c|}{ Within Groups } & $\begin{array}{r}272.68 \\
1 \\
\end{array}$ & 60 & 4.545 & & \\
\hline & \multicolumn{2}{|l|}{ Total } & $\begin{array}{r}1908.7 \\
50 \\
\end{array}$ & 79 & & & \\
\hline
\end{tabular}


Based on the table 4 above, the Sig. value from Deviation from Linearity column is 0.321 which is higher than 0.05. It means that the regression line which indicates the effect of vocabulary mastery (X2) on students' reading comprehension (Y) is linear.

To sum up, regression line of both grammar mastery and vocabulary mastery on students' reading comprehension which illustrates the effects are stated in the linear position according to SPSS version 20.0 for Windows computation.

\section{Multicollinearity Test}

Multicollinearity test is aimed to test whether the regression model found a perfect correlation between the independent variables. A good regression model occurs when there is no perfect correlation between the independent variables. The result of multicollinearity test in this research is shown in the following table.

Table 5. Multicollinearity Test

\begin{tabular}{|c|c|c|c|}
\hline \multirow[t]{2}{*}{ Model } & & \multicolumn{2}{|c|}{ Collinearity Statistics } \\
\hline & & Tolerance & VIF \\
\hline \multirow{3}{*}{1} & (Constant) & & \\
\hline & Grammar Mastery & .406 & 2.465 \\
\hline & Vocabulary Mastery & .406 & 2.465 \\
\hline
\end{tabular}

a. Dependent Variable: Reading Comprehension

From the table above, it is known that the value of tolerance is $0.406>0.1$ and the value of VIF is $2.465<10$. It means, there is no multicollinearity problem between grammar and vocabulary mastery in this multiple regression analysis.

\section{Heteroscedasticity Test}

One of the methods for detecting the presence of heteroscedstidity is to make a scatter-plot between the standardized residual (ZRESID) and the Standardized Predicted Value (ZPRED). In this research, the problem of heteroscedasticity was detected by seeing the scatter-plot through SPSS version 20.0 for Windows. The result of heteroscedasticity test in this research can be shown in the following figure.

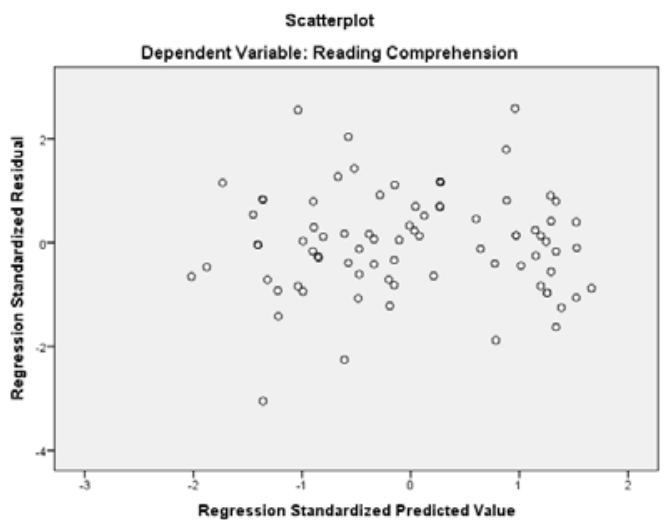

Figure 5. Scatterplot of Heteroscedasticity Test The figure 5 above shows that the dots spread randomly and do not form a clear specific pattern. It means there is no heteroscedasticity problem in this regression model.

\section{Test of Hypothesis}

Test of hypothesis was done based on statistical hypothesis in the last part of chapter III. The recapitulations of the entire test can be seen in the set of following tables:

Table 6. Multiple Correlation Coefficients of the Effects of X1 and X2 on Y

\begin{tabular}{|c|c|c|c|c|}
\hline & \multicolumn{4}{|c|}{ Model Summary } \\
\hline Model & $\mathrm{R}$ & R Square & $\begin{array}{l}\text { Adjusted R } \\
\text { Square }\end{array}$ & $\begin{array}{l}\text { Std. Error of } \\
\text { the Estimate }\end{array}$ \\
\hline 1 & $.910^{\mathrm{a}}$ & .828 & .824 & 2.063 \\
\hline
\end{tabular}

Table 7. Regression Coefficient Significance Test of the Effects of X1 and X2 on Y

\begin{tabular}{|c|c|c|c|c|c|c|}
\hline \multicolumn{7}{|c|}{ ANOVA $^{a}$} \\
\hline & & Sum of & Df & Mean & $\mathrm{F}$ & Sig. \\
\hline \multirow{3}{*}{1} & $\begin{array}{l}\text { Regressi } \\
\text { on }\end{array}$ & 1581.050 & 2 & 790.525 & $\begin{array}{r}185.75 \\
0\end{array}$ & $.000^{\mathrm{b}}$ \\
\hline & Residual & 327.700 & 77 & 4.256 & & \\
\hline & Total & 1908.750 & 79 & & & \\
\hline
\end{tabular}

Table 8. Linear Regression Equality Test of the Effects of X1 and X2 on Y

\begin{tabular}{|c|c|c|c|c|c|c|}
\hline & & Co & ficients $^{\mathrm{a}}$ & & & \\
\hline & & $\begin{array}{r}\text { Unstand } \\
\text { Coeffi }\end{array}$ & $\begin{array}{l}\text { dized } \\
\text { ents }\end{array}$ & $\begin{array}{l}\text { Standardi } \\
\text { zed }\end{array}$ & $\mathrm{T}$ & Sig. \\
\hline & & B & $\begin{array}{l}\text { Std. } \\
\text { Error }\end{array}$ & Beta & & \\
\hline & (Constant) & .507 & .874 & & .580 & .564 \\
\hline 1 & $\begin{array}{l}\text { Grammar } \\
\text { Mastery }\end{array}$ & .203 & .066 & .227 & 3.066 & .003 \\
\hline & $\begin{array}{l}\text { Vocabulary } \\
\text { Mastery }\end{array}$ & .630 & .065 & .723 & 9.756 & .000 \\
\hline
\end{tabular}

\section{The Effect of Grammar Mastery (X1) and Vocabulary Mastery (X2) Jointly on Students' Reading Comprehension}

Refering to table 6 above, it can be seen that the coefficient correlation of the effect of grammar \& vocabulary mastery jointly on students' reading comprehension is 0.910. It indicates that among variables has very strong effect because $R_{0}$ is close to 1 .

Meanwhile, the coefficient of determination of grammar and vocabulary mastery variables to reading comprehension is 0.828 . It means that the contribution of grammar and vocabulary mastery jointly on students' reading comprehension is $82.8 \%$ and the rest $(17.2 \%)$ is determined by other factors. 
According to table 7 above, we can see that Sig. = $0.000<0.05$ and $F_{0}=185.750$ which means there is a significant effect of grammar and vocabulary mastery jointly on students' reading comprehension.

Based on table 8, we may drag a conclusion that vocabulary mastery contributes more influential than grammar mastery since the Sig. value of it $(0.000)$ is lower the Sig. value of grammar mastery (0.003). Indeed, vocabulary mastery has an important role to help a student understand the meaning of the words throughout reading comprehension. By having a set of grammar mastery, it does not mean that someone would be able to comprehend the reading materials automatically. It must be enhanced by enriching activity such as studying vocabularies so that he/she can comprehend the reading materials as well. Even though the effect of grammar mastery is not as strong as vocabulary mastery, it could be a modality for a student to take an advanced activity in order to comprehend the reading materials.

\section{The Effect of Grammar Mastery (X1) on Students' Reading Comprehension (Y)}

Refering to table 8 above, it can be seen that Sig. = $0.003<0.05$ and $t_{0}=3.066$. It means that there is a significant effect of grammar mastery (X1) on students' reading comprehension (Y).

According to the theoretical review, reading comprehension is understanding a text that is read, or the process of constructing meaning from a text. Operationally, the reading comprehension can be measured by using a set of objective test, which is done by students. It goes the same with grammar mastery test. It means that grammar may affect the one's ability to comprehend the reading materials.

Meanwhile, grammar is an important part of a language because if the sentences are in ungrammatical pattern, it can make the reader difficult to get the ideas; yet, if the reader has knowledge of grammar, they can easily fix them and catch the ideas of the sentences. In other words, grammar may help students understand what they read. Without it, one will be difficult to know the meaning of sentence in the context of communication.

From the theoretical review above, it can be assumed that the higher the level of grammar mastery possessed by the students especially correlated to reading domain, the higher the possibility to achieve good reading comprehension. In other words, students should have good grammar mastery if they want to convey the meaning of reading materials more easily.

To sum up, both the quantitative information and theoretical review, the writer comes to the conclusion that the grammar mastery level brings positive and significant effect on students' reading comprehension.

\section{The Effect of Vocabulary Mastery (X2) on Students' Reading Comprehension (Y)}

Refering to table 8 above, it can be seen that Sig. = $0.000<0.05$ and $t_{0}=9.756$. It means that there is a significant effect of vocabulary mastery (X2) on students' reading comprehension (Y).

According to the theoretical review, vocabulary is knowledge of words and word meaning in both oral and written language and in productive and receptive forms. More specifically, vocabulary refers to the kind of word that students must know to read increasingly demanding text with comprehension.

In addition, Harmer (2002: 13) points out that without grammar, very little can be conveyed, but without vocabulary nothing can be conveyed. It means that existence of vocabulary cannot be separated by the existence of a language. In other words, no language exists without vocabulary. Therefore, vocabulary is important in language learning to develop students' language skills, especially in reading. Students should have adequate vocabulary so that they can understand about the reading materials.

From the theoretical review above, it can be assumed that the higher the level of vocabulary mastery possessed by the students especially correlated to reading domain, the higher the possibility to achieve the reading comprehension.

To sum up, both the quantitative information and theoretical review, the writer comes to the conclusion that the vocabulary mastery level brings positive and significant effect on students' reading comprehension.

\section{Regression Line Equation}

According to regression analysis which is used to test the hypothesis, we may get the set of data stated in table 4.7 above. The regression line equation which represents the effect of grammar and vocabulary mastery on students' reading comprehension is as follow:

$\hat{\mathrm{Y}}=0.507+0.203 \mathrm{X} 1+0.630 \mathrm{X} 2$

$\hat{\mathrm{Y}} \quad$ : dependent variable

$\mathrm{X}$ : independent variables

Explanation:

a. The value of constant is 0.507 . It means if the independent variables are considered constant, the students' reading comprehension value is 0.507 .

b. The value of regression coefficient of $\mathrm{X} 1$ is 0.203 . It means that each addition of one unit of grammar mastery will have an impact on the 
increased students' reading comprehension in the amount of 0.203 .

c. The value of regression coefficient of $\mathrm{X} 2$ is 0.630 . It means that each addition of one unit of vocabulary mastery will have an impact on the increased students' reading comprehension in the amount of 0.630 .

\section{CONCLUSION}

Some conclusions of this research can be presented as follows:

1. There is a significant effect of grammar and vocabulary mastery jointly on students' reading comprehension.

2. There is a significant effect of grammar mastery on students' reading comprehension.

3. There is a significant effect of vocabulary mastery on students' reading comprehension.

This research is still very short in detail. Hence, we need to conduct further research to find out more about grammar mastery, vocabulary mastery, and reading comprehension.

\section{REFERENCES}

Cook, S. and Sutter, R.W. (1980). The Scope of Grammar: A Study of Modern English. New York: McGraw-Hill.

Harmer, J. (1991). The Practice of English Language Teaching. New York: Longman.

Harmer, J. (2002). The Practice of English Language Teaching. Harlow: Longman.

Hatch, E and .Brown, C. (1995). Vocabulary, Semantics and Language Education. Cambridge: Cambridge University Press.
Hornby, A.S. (1995). Oxford Advanced Learner's Dictionary of Current English. New York: Oxford University Press.

Kamil, M.L., Hiebert, E.H. (2004). The teaching and learning of vocabulary perspectives and persistent issues. New Jersey: Lawrence Erlbaum Associates Publishers.

Knapp, P. \& Watkins, M. (2005). Genre, Text, Grammar: Technologies for Teaching and Assessing Writing. Sydney: University of New South Wales Press.

Nunan, D. (1999). Research Methods in Language Learning. Cambridge: Cambridge Univeristy Press.

Sasmoko. (2004). Metode Penelitian. Jakarta: UKI Press.

Swan, M. (2005). Grammar: Oxford Introductions to Language Study. New York: Oxford University Press.

Thornbury, S. (2007). How to Teach Vocabulary. Essex: Pearson Longman.

Ur, P. (1991). A Course in Language Teaching (Practice and Theory). Great Britain: Cambridge University Press.

Wilkins, D.A. (1972). Linguistic in Language Teaching. London: Arnold.

Lado, R. (1961). Language Learning Vol. 11, March 1961: Linguistics and Foreign Language Teaching. Michigan: University of Michigan.

Sugiyono. (2013). Metode Penelitian Pendidikan Pendekatan Kuantitatif, Kualitatif, dan R\&D. Bandung: Alfabeta.

Swan, M. (1985). ELT Journal Vol. 39: A Critical Look at the Communicative Approach. London: The British Council. 